\title{
The clinicopathological features and prognostic value of lymphovascular invasion in patients with upper tract urinary carcinoma after radical nephroureterectomy: an updated systematic review and meta-analysis.
}

\author{
Lijin Zhang ( $\nabla$ stzlj913729553@163.com ) \\ jiangyin people's hospital \\ Bin Wu \\ jiangyin people's hospital \\ Zhenlei Zha \\ jiangyin people's hospital \\ Hu Zhao \\ jiangyin people's hospital \\ Jun Yuan \\ jiangyin people's hospital \\ Yejun Feng \\ jiangyin people's hospital
}

\section{Research article}

Keywords: lymphovascular invasion; upper tract urinary carcinoma; radical nephroureterectomy; prognosis; meta-analysis.

Posted Date: November 4th, 2019

DOI: https://doi.org/10.21203/rs.2.16870/v1

License: (c) (i) This work is licensed under a Creative Commons Attribution 4.0 International License. Read Full License 


\section{Abstract}

Background and Purpose: Although the prognostic value of lymphovascular invasion (LVI) for upper tract urinary carcinoma (UTUC) have been described. There is lack of consensus regarding the prognostic factor of LVI in UTUC. The aim of present study was to evaluate the current evidence regarding the contemporary role of LVI through systematic review and metaanalysis according to the updated literatures. Materials and Methods: In the light of Preferred Reporting Items for Systematic Reviews and Meta-analysis (PRISMA) guidelines, a systematic search of Web of Science, PubMed and EMBASE was performed for all reports published until July 2019 that included detailed results on the predictors of LVI. Results: Our meta-analysis included thirty one eligible studies containing 14,653 UTUC patients (81-1,363 per study). According to our final results, there was a significant correlation of LVI with worse cancer-specific survival (CSS) (HR=1.62, 95 \% Cl: 1.49-1.76, $\mathrm{p}<0.001)$, overall survival (OS) (HR=1.55, 95 \% Cl: 1.41-1.71, $\mathrm{p}<0.001)$, recurrence-free survival (RFS) (HR=1.46, $95 \% \mathrm{Cl}$ : $1.32-1.61, p<0.001)$, cancer-specific mortality (CSM) (HR=1.25, $95 \% \mathrm{Cl}: 1.00-1.56, \mathrm{p}=0.047)$ and recurrence $(\mathrm{HR}=1.23,95 \%$ $\mathrm{Cl}: 1.03-1.48, \mathrm{p}=0.026)$. In addition, LVI was also correlated with advanced TNM stage (III/IV vs. I/II: OR $=7.63,95 \% \mathrm{Cl}$ : 5.60-10.39, $p<0.001$ ), higher tumor grade ( 3 vs. $1 / 2$ : OR $=5.61,95 \% \mathrm{Cl}: 3.71-8.48, \mathrm{p}<0.001$ ), lymph node metastasis (yes vs. no: $\mathrm{OR}=4.95,95 \% \mathrm{Cl}$ : 3.66-6.71, $\mathrm{p}<0.001$ ), carcinoma in situ (yes vs. no: $\mathrm{OR}=1.92,95 \% \mathrm{Cl}: 1.36-2.70, \mathrm{p}<0.001$ ) and positive surgical margin (yes vs. no: $\mathrm{OR}=4.38,95 \% \mathrm{Cl}: 2.71-7.07, \mathrm{p}<0.001$ ), but not related to gender (male vs. female: OR $=0.98,95 \% \mathrm{Cl}: 0.80-1.19, \mathrm{p}=0.825$ ) and multifocality (multifocal vs. unifocal: OR $=1.10,95 \% \mathrm{Cl}: 0.82-1.47, \mathrm{p}=0.539$ ). The funnel plot test indicated that no significant publication bias in the meta-analysis. Conclusions: This study demonstrated that LVI was associated with more aggressive clinicopathological features and could serve as a poor prognostic factor for patient with UTUC after radical nephroureterectomy.

\section{Background}

Upper tract urothelial carcinoma (UTUC) arises from the urothelium that lines renal pelvis and the ureter, which accounts for approximately $5 \%$ of all urothelial carcinoma[1]. Although radical nephroureterectomy (RNU) with bladder cuff excision is the gold standard curative therapy for localized UTUC, about 33\% patients with RNU will experience early tumor recurrence within 5 years[2], and the 5-year cancer-specific survival (CSS) is less than $50 \%$ for early stage UTUC patients[3]. Owing to the aggressive features of UTUC, comprehensive recognition of potential prognostic factors is important to improve the prediction of oncologic outcomes.

Lymphovascular invasion, which defined as the presence of tumor cells within lymphatic or vascular channels, is a significant and crucial step in tumor distant metastasis[4,5]. The prognostic value of LVI has been established for bladder cancer, and European guidelines recommend the description of LVI in cystectomy specimens as an independent prognostic factor[6]. In 2013, a meta-analysis by Ku et al[7]. examined 17 studies and confirmed the significant prognostic role of LVI in RNU specimens. However, lots raw data were lost from the included literatures in his paper. Besides, no further study was conducted for the relationship between LVI and other clinicopathological features. In recent years, many studies have added the latest relevant reports. These newly reported studies add information regarding the clinicopathological implications of LVI. Therefore, the purpose of the study was to investigate the relationship between LVI and clinical outcome in UTUC patients so that further understanding of prognostic values of LVI and make a clinical decision that is suitable for the individual quickly.

\section{Methods}

\section{Literature search strategy}

According with Preferred Reporting Items for Systematic Review and Meta-analysis (PRISMA) guidelines[8]. A computerized search from PubMed, EMBASE, Web of Science was conducted by two authors (ZLZ, HZ) in July 2019 to identify studies reporting the incidence of LVI in patients with UTUC undergoing RNU. The combination of the following keywords were used: ("upper urinary tract tumor" OR "renal pelvis" OR "ureter") AND ("radical nephroureterectomy") AND 
("lymphovascular invasion") AND ("prognosis" OR "clinical outcome" OR "survival"). The language of literatures was restricted to English. At the same time, we also manually screened the reference lists of included papers, including all the relevant studies and reviews. Besides, for the data was got from published studies, no ethical approval and informed consent were required.

\section{Study inclusion and exclusion criteria}

The following inclusion criteria were used to select eligible studies: (a) the diagnosis of UTUC and LVI were pathologically confirmed; (b) treatment was limited to radical nephroureterectomy;(c) the prognostic value(hazard ratios (HRs) and 95\% confidence intervals (95\% Cls)) of LVI for overall survival (OS), CSS, recurrence-free survival (RFS), cancer-specific mortality (CSM) and recurrence risk were reported. Accordingly, the exclusion criteria of the meta-analysis were: (a) studies that were not written in English; (b) meeting abstracts, reviews, review papers or case reports; (c) there are no sufficient data to estimate the HRs and 95\% Cls; (d) if more than one articles from one patients cohort were identified, the most complete one was selected.

\section{Data extraction}

Two authors (JY and YJF) independently extracted data from the included studies with a predefined data extraction form. Discrepancies were resolved through discussion by a third author (BW) if necessary. The following variables were recorded: patients' characteristics (first author's name, year of publication, geographical region, number of patients, ages, gender, study period, follow-up duration), tumor characteristics (TNM stage, tumor grade, LVI, lymph node metastasis, tumor multifocality, tumor necrosis, positive surgical margin) and the outcomes of interest. Our primary outcome including OS, CSS, RFS, CSM and recurrence. When multivariate analysis and univariate analysis results were both presented in the one study, we choose multivariate analysis result, as it accounts for confounding factors and more accurate.

\section{Quality assessment}

The quality of the selected studies was assessed by the Newcastle Ottawa Scale (NOS)[9], which was recommended for the assessment of non-randomized studies. This scale assesses risk in three domains: patient selection, comparability of control and intervention groups and assessment of outcomes. A score of 0-9 stars was allocated to each study. We defined high quality as a score of 6-9 and low quality as a score $<6$.

\section{Statistical analysis}

Effect measures for the outcomes of OS, CSS, RFS, CSM and recurrence were HRs and 95\%Cls extracted from published studies. The heterogeneity across studies was tested by performing Cochran's Q test and Higgins $\vdash$ squared statistic. There was marked heterogeneity if the $P$ value was less than 0.10 and/or $I^{2}>50 \%$. A random-effects (RE) model was applied to pool results under significant heterogeneity; otherwise, a fixed-effects (FE) model was applied. A pooled HR greater than 1 indicated a poor survival for the patients with a LVI expression. The source for inter-study heterogeneity were explored by using subgroup analysis. By assessing the asymmetry of funnel plot, publication bias was evaluated. Furthermore, Egger's funnel plots test, which provide quantitative evidence, were employed to search for publication bias between the studies. To examine the stability and reliability of the overall meta-analysis results, we performed the sensitivity analysis by excluding one study in turn. Statistical analyses were conducted with Stata 12.0 software (StatCorp, College Station, TX, USA). All $P$ values were two sided, and $P<0.05$ was defined to be statistically significant.

We also studied the associations between LVI and clinicopathological parameters of UTUC. Information about tumor grade (3 vs. 1/2), TNM stage (III/IV vs. I/II), lymph node metastasis (yes vs. no), carcinoma in situ (yes vs. no), positive surgical margin (yes vs. no), multifocality (multifocal vs. unifocal), gender (male vs. female) were dichotomized. The event numbers were obtained from original studies, and the odds ratio (ORs) and corresponding 95\% Cls were calculated. 


\section{Results}

\section{Search results}

The initial search yielded 998 references, and 539 studies were excluded because of duplication. After title and/or abstracts screening, 169 articles remained for full-text assessment, and 290 articles were excluded, including reviews, letters, meeting abstracts, and other articles irrelevant to our study. In accordance with the study inclusion criteria, 138 articles were excluded for repeated crowds or without enough extratable data. Finally, thirty-one studies were retrospective design were included in this meta-analysis. A flow diagram about the literature search and study selection process is presented in Figure 1.

\section{Features of included studies}

Summary characteristics of these studies are shown in Table 1. A total of 14,653 UTUC patients (ranged from 81-1363) were included. The median or mean age of patients ranged from 62 to 71 years. The 31 included articles were published from 2009 to 2019. Geographically, 20 studies were conducted in Asia, 7 in Muti-centers, 2 in USA, 1 in France and 1 in Serbia. All patients had received RNU as primary treatment for UTUC. Of this studies, 12 studies reported OS, 24 studies reported CSS, 14 studies reported RFS, 5 studies reported CSM and 6 studies reported recurrence. The characteristics of tumor features and pathologic outcomes are summarized in Table 2. LVI was detected in $(3,635 / 14,653) 24.8 \%$ in pathological specimens of the included patients. According to the NOS, we assessed the quality of the 31 eligible studies[1040]. The quality scores of the studies varied from 7 to 9 , with a mean of 8.7, which means that all the studies were of high quality. (Supplementary Table S1)

\section{Meta-analysis results}

The pooled result indicated that the presence of LVI in UTUC specimen was associated with poor CSS (RE model, HR=1.62, $95 \% \mathrm{Cl}: 1.49-1.76, p<0.001 ; \boldsymbol{R}=69.9 \%$; Figure 2), OS (RE model, $\mathrm{HR}=1.55,95 \% \mathrm{Cl}: 1.41-1.71, p<0.001 ; \boldsymbol{R}=73.2 \%$; Figure 3A), RFS ( $\mathrm{RE}$ model, $\mathrm{HR}=1.46,95 \% \mathrm{Cl}$ : 1.32-1.61, $p<0.001 ; \boldsymbol{R}=78.6 \%$; Figure 3B), CSM (RE model, $\mathrm{HR}=1.25,95 \% \mathrm{Cl}$ : 1.00-1.56, $p=0.047 ; \mathrm{p}<0.001 ; \boldsymbol{R}=91.6 \%$; Figure $3 \mathrm{C}$ ) and recurrence (RE model, $\mathrm{HR}=1.23,95 \% \mathrm{Cl}: 1.03-1.48, p=0.026 ; \boldsymbol{R}=$ $89 \%$; Figure 3D). To explore the heterogeneity for CSS, OS, RFS, the prognostic value of LVI was evaluated further via subgroup analysis under the geographical region (Asia vs. non-Asian), year of publication ( $\geq 2014 \mathrm{vs.}<2014$ ), TNM stage $(\mathrm{T} 3+\mathrm{T} 4 \%)$ ( $\geq 40$ vs. $<40$ ), tumor grade (G2+G3 \%) ( $\geq 60$ vs. $<60)$, No. of patients $(\geq 500$ vs. $<500)$ and median follow-up ( $\geq 40$ months vs. $<40$ months) (Table 3). Because of too few cohorts in the CSM and recurrence group, no subgroup analysis was conducted. The results in subgroup analyses were consistent with the primary findings, which suggested LVI still as a prognostic factor despite heterogeneity among some groups. Although no significant changes for the inter-study heterogeneity were detected, the observed heterogeneity dropped significantly in some subgroup models, such as No. of patients $<500$, Grade $(\mathrm{G} 3+\mathrm{G} 4 \%) \geq 60$.

The risk estimate with pooled ORs were used to assess the associations between the LVI and clinicopathological parameters in UTUC patients. As shown in Table 4, LVI was significantly related to TNM stage (III/IV vs. I/II: OR $=7.63,95 \% \mathrm{Cl}: 5.60-$ $10.39, p<0.001$ ) (Supplementary Figure 1A), higher tumor grade (3 vs. 1/2: OR = 5.61, 95\% Cl: $3.71-8.48, p<0.001$ ) (Supplementary Figure 1B), lymph node metastasis(LNM) (yes vs. no: $\mathrm{OR}=4.95,95 \% \mathrm{Cl}: 3.66-6.71, p<0.001$ ) (Supplementary Figure 1C), CIS (yes vs. no: OR = 1.92, 95\% Cl: 1.36-2.70, $p<0.001$ ) (Supplementary Figure 1D) and positive surgical margin(PSM) (yes vs. no: $\mathrm{OR}=4.38,95 \% \mathrm{Cl}: 2.71-7.07, p<0.001$ ) (Supplementary Figure 1E), but not related to gender (male vs. female: $\mathrm{OR}=0.98,95 \% \mathrm{Cl}: 0.80-1.19, p=0.825$ ) (Supplementary Figure 2A) and multifocality (multifocal vs. unifocal: $\mathrm{OR}=1.10,95 \% \mathrm{Cl}: 0.82-1.47, p=0.539$ ) (Supplementary Figure $2 \mathrm{~B}$ ) . No significant heterogeneity were observed in those groups.

In sensitivity analyses omitting enrolled studies in turn, the results showed that the pooled HRs did not alter significantly which suggested that the findings were reliable and robust. (Supplementary Figure 3). 


\section{Publication bias}

We conducted the publication bias assessment of the studies by funnel plots and Egger's test. As shown in Figure 4, No obvious asymmetry was founded in all groups. The $P$-values of the Egger's test were all greater than 0.05 in CSS ( $p$-Egger $=$ 0.701, Figure 4A), OS ( $p$-Egger $=0.330$, Figure 4B), RFS ( $p$-Egger $=0.811$, Figure 4C), CSM $(p$-Egger $=0.984$, Figure 4D $)$ and recurrence $(p$-Egger $=0.843$, Figure 4E).

\section{Discussion}

UTUC is a rare urothelial carcinoma compared with bladder cancer, however, the incidence of UTUC has increased significantly over the past decade[41]. Although we have done our best to improve the knowledge of UTUC, its management remains challenging. Even after standard surgery of RNU in majority of UTUC patients, there are still some patients with poor postoperative outcomes. Therefore, it is very important to accurately predict the prognosis of patients after RUN, which can better help us to predict the clinical prognosis outcomes in UTUC patients. To date, many studies have been conducted to identify the significant prognostic factors of UTUC. Some traditional prognostic predictors, such as pathologic characteristics of RNU specimens including tumor stage and grade[39], tumor architecture[20], tumour size[23] and CIS[42] had been found as significant prognostic variables for CSS and RFS in different studies.

LVI was considered to be the first step in the metastasis of tumor cells and LNM[29]. Recently, mounting evidences have indicated that LVI is associated with poor prognosis for many kinds of tumors, such as liver, bladder, and prostate cancer[43,6]. Jiang et al.[5] reported that LVI is an independent prognostic factor to predict worse progression in prostate cancer, and they recommended that LVI should be reported in the final pathological diagnosis after radical prostatectomy. Similarly, Canter et al.[44] found that the presence of LVI in the final pathological reports for bladder cancer deliver significant risks for worse CSS and OS. Some studies suggest that LVI can be used as an independent prognostic factor in patients with UTUC after RNU[28,35]. However, some studies suggest that the prognostic value of LVI in assessing survival outcome is meaningless[27,45], which remains the prognostic value of LVI need to be clarified and summarized.

Based on previous researches, the positive rate of LVI in the final pathology report is approximately $15-30 \%$ in patients with UTUC after surgery $[29,7,38]$. Consistent with previous reports, we found that LVI was appeared in about $24.8 \%$ of patients. LVI is an easily accessible pathological parameter, which can be accurately measured among observers. Hurel et al.[35] in their study involving 551 patients, have concluded that the presence of LVI was an independent risk factor for UTUC. Likewise, Lee et al.[29] reported significant association between LVI and tumor grade, tumor stage, and LNM. Although it has been proposed that LVI should be accurately recorded in pathological reports for UTUC specimens, there are still controversial data about the impact of LVI on patient prognosis and survival. For example, Jan et al.[12] recently reported that LVI cm was not associated with OS and CSS on multivariate analysis. Besides, Eich et al.[46] founde that LVI was not associated with tumor progression, total mortality and CSM.

Although the previous studies has largely promoted our knowledge of UTUC, they were limited to small sample sizes and heterogeneous populations. To overcome these shortcomings and better understand the clinical value of LVI, we assessed the LVI and 14,653 patients treated with RNU for UTUC through meta-analysis. In this study, we demonstrated that LVI was an independent prognostic factor for CSS, RFS, OS, CSM and recurrence among patients with UTUC treated with RNU. In some studies, LVI has been related worse tumor differentiation, higher stage and grade, LNM and PSMs. Consistent with previous finds, our results indicated that LVI was associated with the above clinicopathological features, which are all independent poor prognostic factors. All results strongly supported the prognostic value of LVI on poor outcomes in UTUC plays a promoting role in tumor progression. Furthermore, the results of the study may provide a postoperative follow-up protocol for UTUC patients to evaluate the prognostic value of LVI. Interestingly, no obvious association between LVI and multifocality were founded in our study. Although multifocal tumors had a worse oncological ending than renal pelvic tumors, the role of tumor location was not confirmed yet[47]. Hence, multifocal tumors may arise from a more aggressive carcinogenesis pathway. 
The results obtained in this study are mainly in line with the previous system review by Ku et al.[7] However, our study presented series of advancement. At first, the Ku's search time was ended in 2013. However, we added 23 extra studies including 10,963 patients, thereby allowing us to perform a subgroup analyses with more exact evaluation for LVI. Besides, the quality of NOS involving in present meta-analysis was greater, which strengthened the persuasiveness of this research. With the stupendous prognostic value of LVI, we suggest that LVI should always be presented in the pathologic report of RNU specimens. Moreover, patients with LVI expression maybe given intensive treatment after RNU. Unfortunately, we are unable to further explore the relationship between LVI and postoperative therapy (radiotherapy or chemotherapy) due to the insufficient data in this study.

Our study had several limitations should be acknowledged. First, literatures were mainly retrospective, with an obviously heterogeneity in our study. The subgroup analysis to identify the source of heterogeneity was conducted in the present study. Although the great heterogeneity among studies had no effect on the pooled result, the heterogeneity should not be neglected completely. Thus, the conclusions yielded in this study may be interpreted with caution. Second, the studies in our paper were mainly done in 4 regions, including Asia, Europe, USA, and multi-institutional studies. The observed differences in statistical results might reflect regional ethnic differences. Third, some other potential risk factors involved in this report may also have affected on the final results. For example, the surgical methods were different. Most RNUs were laparoscopic approaches, but some were done by open surgeries. Thus, the performance bias may generated. Fourth, reporting bias may exist in our research, as some studies with negative results may not are not inclined to been published. However, no significant bias was observed in this research, which indicating that our results were stable and reliable.

\section{Conclusions}

In summary, our meta-analysis suggests the fact that LVI is associated with unfavorable prognosis and clinicopathological features in patients with UTUC. Given its convenience and inexpensiveness in clinical application, LVI could be a useful tool for the prediction of prognosis and outcomes of UTUC. However, further prospective multicenter studies should be carried out to confirm our findings, for certain limitations were been observed in our meta-analysis.

\section{Abbreviations}

LVI: Iymphovascular invasion; UTUC: upper tract urinary carcinoma; RNU: radical nephroureterectomy; PRISMA: Preferred Reporting Items for Systematic Reviews and Meta-Analyses; NOS: Newcastle-Ottawa scale; HRs: hazard ratios; ORs: odds ratio; Cls: confidence intervals; CSS: cancer-specific survival; OS: overall survival; RFS: recurrence-free survival; CSM: cancerspecific mortality; CIS: concomitant carcinoma in situ; LNM: lymph node metastasis; PSM: positive surgical margin.

\section{Declarations}

\section{Ethics approval and consent to participate}

Not applicable

\section{Consent to publish}

I give my consent for information about my relative circle to be published in $\mathrm{BMC}$ cancer. I understand that the information will be published without my relative's (circle as appropriate) name attached, but that full anonymity cannot be guaranteed. I understand that the text and any pictures or videos published in the article will be freely available on the internet and may be seen by the general public. The pictures, videos and text may also appear on other websites or in print, may be translated into other languages or used for commercial purposes. I have been offered the opportunity to read the manuscript.

\section{Availability of materials and data}


All data generated or analyzed during this study are included in this published article

\section{Competing interests}

We declare that there have no potential competing interests in this research.

\section{Funding}

No funding was supposed in our study

\section{Acknowledgements}

Not applicable

\section{Authors' Contributions}

LJ Zhang: Project development and Manuscript writingB Wu: Data Management and Manuscript editingJ Yuan: Data CollectionYJ Feng: Data Collection ZL Zha: Data analysis, Data ManagementH Zhao: Data analysis, Data Management

\section{References}

1. Siegel RL, Miller KD (2019) Cancer statistics, 2019. 69 (1):7-34. doi:10.3322/caac.21551

2. Cha EK, Shariat SF, Kormaksson M, Novara G, Chromecki TF, Scherr DS, Lotan Y, Raman JD, Kassouf W, Zigeuner R, Remzi M, Bensalah K, Weizer A, Kikuchi E, Bolenz C, Roscigno M, Koppie TM, Ng CK, Fritsche HM, Matsumoto K, Walton TJ, Ehdaie B, Tritschler S, Fajkovic H, Martinez-Salamanca JI, Pycha A, Langner C, Ficarra V, Patard JJ, Montorsi F, Wood CG, Karakiewicz PI, Margulis V (2012) Predicting clinical outcomes after radical nephroureterectomy for upper tract urothelial carcinoma. European urology 61 (4):818-825. doi:10.1016/j.eururo.2012.01.021

3. Roupret M, Babjuk M, Comperat E, Zigeuner R, Sylvester RJ, Burger M, Cowan NC, Bohle A, Van Rhijn BW, Kaasinen E, Palou J, Shariat SF (2015) European Association of Urology Guidelines on Upper Urinary Tract Urothelial Cell Carcinoma: 2015 Update. European urology 68 (5):868-879. doi:10.1016/j.eururo.2015.06.044

4. Ukai R, Hashimoto K, Nakayama H, Iwamoto T (2017) Lymphovascular invasion predicts poor prognosis in high-grade pT1 bladder cancer patients who underwent transurethral resection in one piece. Jpn J Clin Oncol 47 (5):447-452. doi:10.1093/jjco/hyx012

5. Jiang W, Zhang L, Wu B, Zha Z, Zhao H, Jun Y, Jiang Y (2018) The impact of lymphovascular invasion in patients with prostate cancer following radical prostatectomy and its association with their clinicopathological features: An updated PRISMA-compliant systematic review and meta-analysis. Medicine 97 (49):e13537. doi:10.1097/md.0000000000013537

6. Mari A, Kimura S, Foerster B, Abufaraj M, D'Andrea D, Gust KM, Shariat SF (2018) A systematic review and metaanalysis of lymphovascular invasion in patients treated with radical cystectomy for bladder cancer. Urologic oncology 36 (6):293-305. doi:10.1016/j.urolonc.2018.03.018

7. Ku JH, Byun SS, Jeong H, Kwak C, Kim HH, Lee SE (2013) Lymphovascular invasion as a prognostic factor in the upper urinary tract urothelial carcinoma: a systematic review and meta-analysis. European journal of cancer (Oxford, England : 1990) 49 (12):2665-2680. doi:10.1016/j.ejca.2013.04.016

8. Liberati A, Altman DG, Tetzlaff J, Mulrow C, Gotzsche PC, loannidis JP, Clarke M, Devereaux PJ, Kleijnen J, Moher D (2009) The PRISMA statement for reporting systematic reviews and meta-analyses of studies that evaluate healthcare interventions: explanation and elaboration. BMJ (Clinical research ed) 339:b2700. doi:10.1136/bmj.b2700

9. Stang A (2010) Critical evaluation of the Newcastle-Ottawa scale for the assessment of the quality of nonrandomized studies in meta-analyses. European journal of epidemiology 25 (9):603-605. doi:10.1007/s10654-010-9491-z 
10. Liu W, Zhou Z (2019) Prognostic Value of Lymphovascular Invasion in Node-Negative Upper Urinary Tract Urothelial Carcinoma Patients Undergoing Radical Nephroureterectomy. 60 (2):174-181. doi:10.3349/ymj.2019.60.2.174

11. Li Y, Fang D, Bao Z, He A, Guan B, He S, Zhan Y, Gong Y, Li X, Zhou L (2019) High aspartate transaminase/alanine transaminase ratio predicts poor prognosis in patients with localized upper tract urothelial cancer: a propensity scorematched study in a large Chinese center. OncoTargets and therapy 12:2635-2648. doi:10.2147/ott.s193771

12. Jan HC, Yang WH, Ou CH (2019) Combination of the Preoperative Systemic Immune-Inflammation Index and MonocyteLymphocyte Ratio as a Novel Prognostic Factor in Patients with Upper-Tract Urothelial Carcinoma. Annals of surgical oncology 26 (2):669-684. doi:10.1245/s10434-018-6942-3

13. Aydin AM, Singla N, Panwar V, Woldu SL, Freifeld Y, Wood CG, Karam JA, Weizer AZ, Raman JD, Remzi M, RiouxLeclercq N, Haitel A, Roscigno M, Bolenz C, Bensalah K, Westerman ME, Sagalowsky Al, Shariat SF, Lotan Y, Bagrodia A, Kapur P, Margulis V (2019) Prognostic significance of BAP1 expression in high-grade upper tract urothelial carcinoma: a multi-institutional study. doi:10.1007/s00345-019-02678-x

14. Tan P, Xie N, Liao H, Zou L, Xu H, Yang L, Liu L, Wei Q (2018) Prognostic impact of preoperative anemia on upper tract urothelial carcinoma. Medicine 97 (37):e12300. doi:10.1097/md.0000000000012300

15. Kohada Y, Hayashi T, Goto K, Kobatake K, Abdi H, Honda Y, Sentani K, Inoue S, Teishima J, Awai K, Yasui W, Matsubara A (2018) Preoperative risk classification using neutrophil-lymphocyte ratio and hydronephrosis for upper tract urothelial carcinoma. Jpn J Clin Oncol 48 (9):841-850. doi:10.1093/jjco/hyy084

16. Abe T, Kondo T, Harabayashi T, Takada N, Matsumoto R, Osawa T, Minami K, Nagamori S, Maruyama S, Murai S, Tanabe K, Shinohara N (2018) Comparative study of lymph node dissection, and oncological outcomes of laparoscopic and open radical nephroureterectomy for patients with urothelial carcinoma of the upper urinary tract undergoing regional lymph node dissection. Jpn J Clin Oncol 48 (11):1001-1011. doi:10.1093/jjco/hyy128

17. Nakagawa T, Komemushi Y, Kawai T, Otsuka M, Miyakawa J, Uemura Y, Kanatani A, Taguchi S, Naito A, Suzuki M, Nishimatsu H, Hirano Y, Tanaka Y, Matsumoto A, Miyazaki H, Fujimura T, Fukuhara H, Kume H, Igawa Y, Homma Y (2017) Efficacy of post-nephroureterectomy cisplatin-based adjuvant chemotherapy for locally advanced upper tract urothelial carcinoma: a multi-institutional retrospective study. World J Urol 35 (10):1569-1575. doi:10.1007/s00345-0172032-6

18. Inokuchi J, Eto M, Hara T, Fujimoto H, Nishiyama H, Miyazaki J, Kikuchi E, Hinotsu S, Koie T, Ohyama C (2017) Impact of lymph node dissection on clinical outcomes during nephroureterectomy in patients with clinically node-negative upper urinary tract urothelial cancer: subanalysis of a multi-institutional nationwide case series of the Japanese Urological Association. Jpn J Clin Oncol 47 (7):652-659. doi:10.1093/jjco/hyx051

19. Ikeda M, Matsumoto K, Sakaguchi K, Ishii D, Tabata KI, Kurosawa K, Urakami S, Okaneya T, Iwamura M (2017) Effect of Lymphadenectomy During Radical Nephroureterectomy in Locally Advanced Upper Tract Urothelial Carcinoma. Clinical genitourinary cancer 15 (5):556-562. doi:10.1016/j.clgc.2017.04.004

20. Fan B, Hu B, Yuan Q, Wen S, Liu T, Bai S, Qi X, Wang X, Yang D, Sun X, Song X (2017) Impact of tumor architecture on disease recurrence and cancer-specific mortality of upper tract urothelial carcinoma treated with radical nephroureterectomy. Tumour biology : the journal of the International Society for Oncodevelopmental Biology and Medicine 39 (7):1010428317710822. doi:10.1177/1010428317710822

21. Cho YH, Hwang JE, Chung HS, Kim MS, Hwang EC (2017) The De Ritis (aspartate transaminase/alanine transaminase) ratio as a predictor of oncological outcomes in patients after surgery for upper urinary tract urothelial carcinoma. 49 (8):1383-1390. doi:10.1007/s11255-017-1613-z

22. Abufaraj M, Moschini M, Soria F, Gust K, Ozsoy M, Mathieu R, Roupret M, Margulis V, Karam JA, Wood CG, Briganti A, Bensalah K, Haitel A, Shariat SF (2017) Prognostic role of expression of N-cadherin in patients with upper tract urothelial carcinoma: a multi-institutional study. World J Urol 35 (7):1073-1080. doi:10.1007/s00345-016-1968-2

23. Shibing Y, Liangren L, Qiang W, Hong L, Turun S, Junhao L, Lu Y, Zhengyong Y, Yonghao J, Guangqing F, Yunxiang L, Dehong C (2016) Impact of tumour size on prognosis of upper urinary tract urothelial carcinoma after radical

Page $8 / 20$ 
nephroureterectomy: a multi-institutional analysis of 795 cases. BJU international 118 (6):902-910.

doi:10.1111/bju.13463

24. Kobayashi H, Kikuchi E, Tanaka N, Shirotake S, Miyazaki Y, Ide H, Obata J, Hoshino K, Matsumoto K, Kaneko G, Hagiwara M, Kosaka T, Oyama M, Nakajima Y, Oya M (2016) Patient age was an independent predictor of cancerspecific survival in male patients with upper tract urothelial carcinoma treated by radical nephroureterectomy. Jpn $\mathrm{J}$ Clin Oncol. doi:10.1093/jjco/hyw028

25. Kang SG, Hwang EC, Jung SI, Yu HS, Chung HS, Kang TW, Kwon DD, Hwang JE, Kim JS, Noh JH, You JH, Kim MK, Oh TH, Seo IY, Baik S, Kim CS, Kang SH, Cheon J (2016) Poor Preoperative Glycemic Control Is Associated with Dismal Prognosis after Radical Nephroureterectomy for Upper Tract Urothelial Carcinoma: A Korean Multicenter Study. Cancer research and treatment : official journal of Korean Cancer Association 48 (4):1293-1301. doi:10.4143/crt.2016.021

26. Fukushima H, Nakanishi Y, Kataoka M, Tobisu K, Koga F (2016) Prognostic significance of sarcopenia in upper tract urothelial carcinoma patients treated with radical nephroureterectomy. Cancer Med 5 (9):2213-2220. doi:10.1002/cam4.795

27. Mathieu R, Klatte T, Margulis V, Karam JA, Roupret M, Seitz C, Karakiewicz PI, Fajkovic H, Wood CG, Weizer AZ, Raman JD, Remzi M, Rioux-Leclercq N, Haitel A, Bensalah K, Lotan Y, Rink M, Kluth LA, Scherr DS, Robinson BD, Shariat SF (2015) Survivin is not an independent prognostic factor for patients with upper tract urothelial carcinoma: a multiinstitutional study. Urologic oncology 33 (11):495.e415-422. doi:10.1016/j.urolonc.2015.06.016

28. Lee KS, Kim KH, Yoon YE, Choi KH, Yang SC, Han WK (2015) Impact of adjuvant chemotherapy in patients with upper tract urothelial carcinoma and lymphovascular invasion after radical nephroureterectomy. Korean journal of urology 56 (1):41-47. doi:10.4111/kju.2015.56.1.41

29. Lee HY, Li CC, Huang CN, Ke HL, Li WM, Liang PI, Yang SF, Tu HP, Wu WJ, Yeh HC (2015) Prognostic significance of lymphovascular invasion in upper urinary tract urothelial carcinoma is influenced by tumor location. Annals of surgical oncology 22 (4):1392-1400. doi:10.1245/s10434-014-4103-x

30. Park J, Park S, Song C, Hong JH, Kim CS, Ahn H (2014) Peripelvic/periureteral fat invasion is independently associated with worse prognosis in pT3 upper tract urothelial carcinoma. World J Urol 32 (1):157-163. doi:10.1007/s00345-0131073-8

31. Lee DJ, Xylinas E, Rieken M, Khani F, Klatte T, Wood CG, Karam JA, Weizer AZ, Raman JD, Remzi M, Guo CC, RiouxLeclercq N, Haitel A, Bolenz C, Bensalah K, Sagalowsky Al, Montorsi F, Lotan Y, Shariat SF, Robinson BD, Margulis V (2014) Insulin-like growth factor messenger RNA-binding protein 3 expression helps prognostication in patients with upper tract urothelial carcinoma. European urology 66 (2):379-385. doi:10.1016/j.eururo.2013.12.008

32. Krabbe LM, Westerman ME, Bagrodia A, Gayed BA, Khalil D, Kapur P, Shariat SF, Raj GV, Sagalowsky Al, Cadeddu JA, Lotan Y, Margulis V (2014) Surgical management of the distal ureter during radical nephroureterectomy is an independent predictor of oncological outcomes: results of a current series and a review of the literature. Urologic oncology 32 (1):54.e19-26. doi:10.1016/j.urolonc.2013.08.032

33. Kluth LA, Xylinas E, Kent M, Hagiwara M, Kikuchi E, Ikeda M, Matsumoto K, Dalpiaz O, Zigeuner R, Aziz A, Fritsche HM, Deliere A, Raman JD, Bensalah K, Al-Matar B, Gakis G, Novara G, Klatte T, Remzi M, Comploj E, Pycha A, Roupret M, Tagawa ST, Chun FK, Scherr DS, Vickers AJ, Shariat SF (2014) Predictors of survival in patients with disease recurrence after radical nephroureterectomy. BJU international 113 (6):911-917. doi:10.1111/bju.12369

34. Liu JY, Li YH, Zhang ZL, Ye YL, Liu ZW, Yao K, Dong P, Guo SJ, Jiang LJ, Zhong MZ, Chen W, Han H, Qin ZK, Zhou FJ (2013) Age-specific effect of gender on upper tract urothelial carcinoma outcomes. Medical oncology 30 (3):640. doi:10.1007/s12032-013-0640-6

35. Hurel S, Roupret M, Ouzzane A, Rozet F, Xylinas E, Zerbib M, Berod AA, Ruffion A, Adam E, Cussenot O, Houlgatte A, Phe V, Nouhaud FX, Bensadoun H, Delage F, Guillotreau J, Guy L, Karsenty G, De La Taille A, Colin P (2013) Impact of lymphovascular invasion on oncological outcomes in patients with upper tract urothelial carcinoma after radical nephroureterectomy. BJU international 111 (8):1199-1207. doi:10.1111/bju.12116

Page $9 / 20$ 
36. Milojevic B, Djokic M, Sipetic-Grujicic S, Milenkovic-Petronic D, Vuksanovic A, Bumbasirevic U, Vukovic I, Dragicevic D, Tulic C (2012) Upper urinary tract transitional cell carcinoma: location is not correlated with prognosis. BJU international 109 (7):1037-1042. doi:10.1111/j.1464-410X.2011.10461.x

37. Godfrey MS, Badalato GM, Hruby GW, Razmjoo M, McKiernan JM (2012) Prognostic indicators for upper tract urothelial carcinoma after radical nephroureterectomy: the impact of lymphovascular invasion. BJU international 110 (6):798803. doi:10.1111/j.1464-410X.2011.10893.x

38. Novara G, Matsumoto K, Kassouf W, Walton TJ, Fritsche HM, Bastian PJ, Martinez-Salamanca JI, Seitz C, Lemberger RJ, Burger M, El-Hakim A, Baba S, Martignoni G, Gupta A, Karakiewicz PI, Ficarra V, Shariat SF (2010) Prognostic role of lymphovascular invasion in patients with urothelial carcinoma of the upper urinary tract: an international validation study. European urology 57 (6):1064-1071. doi:10.1016/j.eururo.2009.12.029

39. Kim DS, Lee YH, Cho KS, Cho NH, Chung BH, Hong SJ (2010) Lymphovascular invasion and pT stage are prognostic factors in patients treated with radical nephroureterectomy for localized upper urinary tract transitional cell carcinoma. Urology 75 (2):328-332. doi:10.1016/j.urology.2009.07.1350

40. Margulis V, Shariat SF, Matin SF, Kamat AM, Zigeuner R, Kikuchi E, Lotan Y, Weizer A, Raman JD, Wood CG (2009) Outcomes of radical nephroureterectomy: a series from the Upper Tract Urothelial Carcinoma Collaboration. Cancer 115 (6):1224-1233. doi:10.1002/cncr.24135

41. Raman JD, Messer J, Sielatycki JA, Hollenbeak CS (2011) Incidence and survival of patients with carcinoma of the ureter and renal pelvis in the USA, 1973-2005. BJU international 107 (7):1059-1064. doi:10.1111/j.1464410X.2010.09675.x

42. Redrow GP, Guo CC, Brausi MA, Coleman JA, Fernandez MI, Kassouf W, Keeley FX, Jr., Margulis V, Raman JD, Roupret M, Shariat SF, Spiess PE, Thalmann GN, Matin SF (2017) Upper Urinary Tract Carcinoma In Situ: Current Knowledge, Future Direction. The Journal of urology 197 (2):287-295. doi:10.1016/j.juro.2016.03.194

43. McCleskey BC, Epstein JI, Albany C, Hashemi-Sadraei N, Idrees MT, Jorns JM, Lu DY, Matoso A, Rais-Bahrami S, Schwartz LE, Ulbright TM, Gordetsky J (2017) The Significance of Lymphovascular Invasion of the Spermatic Cord in the Absence of Cord Soft Tissue Invasion. Archives of pathology \& laboratory medicine 141 (6):824-829. doi:10.5858/arpa.2016-0226-0A

44. Canter D, Guzzo T, Resnick M, Magerfleisch L, Sonnad S, Bergey M, Tomazewski J, Vaughn D, Van Arsdalen K, Malkowicz B (2008) The presence of lymphovascular invasion in radical cystectomy specimens from patients with urothelial carcinoma portends a poor clinical prognosis. BJU international 102 (8):952-957. doi:10.1111/j.1464410X.2008.07732.x

45. Yoshida T, Kinoshita H, Shimada S, Sugi M, Matsuda T (2017) Preoperative Pyuria Is a Poor Prognostic Factor in Patients With Urothelial Carcinoma of the Upper Urinary Tract After Surgery. Clinical genitourinary cancer 15 (4):e543e550. doi:10.1016/j.clgc.2016.12.021

46. Eich ML, Tregnago AC, Faraj SF, Palsgrove DN, Fujita K, Bezerra SM, Munari E, Sharma R, Chaux A, Netto GJ (2019) Insulin-like growth factor-1 receptor expression in upper tract urothelial carcinoma. 474 (1):21-27. doi:10.1007/s00428018-2468-0

47. Ouzzane A, Colin P, Xylinas E, Pignot G, Ariane MM, Saint F, Hoarau N, Adam E, Azemar MD, Bensadoun H, Cormier L, Cussenot O, Houlgatte A, Karsenty G, Bruyere F, Maurin C, Nouhaud FX, Phe V, Polguer T, Roumiguie M, Ruffion A, Roupret M (2011) Ureteral and multifocal tumours have worse prognosis than renal pelvic tumours in urothelial carcinoma of the upper urinary tract treated by nephroureterectomy. European urology 60 (6):1258-1265. doi:10.1016/j.eururo.2011.05.049

\section{Tables}

Table 1. Clinical characteristics of the included studies in this meta-analysis 


\begin{tabular}{|c|c|c|c|c|c|c|c|c|c|}
\hline Author & Year & Country & $\begin{array}{l}\text { Recruitment } \\
\text { period }\end{array}$ & $\begin{array}{c}\text { No. of } \\
\text { patients }\end{array}$ & $\begin{array}{c}\text { Age } \\
\text { (years) }\end{array}$ & $\begin{array}{c}\text { Gender } \\
(\mathrm{m} / \mathrm{f})\end{array}$ & $\begin{array}{l}\text { Pelvicalyceal/ } \\
\text { ureteral/both }\end{array}$ & $\begin{array}{l}\text { Follow-up } \\
\text { (months) }\end{array}$ & $\begin{array}{l}\text { Survival } \\
\text { analysis }\end{array}$ \\
\hline $\begin{array}{l}\text { Liu et } \\
\text { al[10] }\end{array}$ & 2019 & China & $2005-2013$ & 180 & $\begin{array}{l}\text { Median } \\
\text { (range) } \\
67.2(39-87)\end{array}$ & $109 / 71$ & NA & $\begin{array}{c}\begin{array}{c}\text { Median } \\
\text { (range) }\end{array} \\
45.4(3-180)\end{array}$ & RFS, CSS \\
\hline Li et al[11] & 2019 & China & 1999-2015 & 885 & $\begin{array}{c}\text { Mean } \pm \text { SD } \\
66.9 \pm 10.6\end{array}$ & $396 / 489$ & $474 / 411$ & $\begin{array}{c}\text { Median (IQR) } \\
61(38-102)\end{array}$ & CSS, OS \\
\hline $\begin{array}{l}\text { Jan et } \\
\text { al[12] }\end{array}$ & 2019 & China & $2007-2017$ & 424 & $\begin{array}{c}\text { Median } \\
\text { (range) } \\
70(29-96) \\
\end{array}$ & $189 / 235$ & $191 / 138 / 95$ & $\begin{array}{c}\text { Median (IQR) } \\
35(14-60)\end{array}$ & CSS, OS \\
\hline $\begin{array}{l}\text { Aydin et } \\
\text { al[13] }\end{array}$ & 2019 & $\begin{array}{c}\text { Muti- } \\
\text { centers }\end{array}$ & 1990-2008 & 348 & $\begin{array}{c}\text { Median (IQR) } \\
70(64-77)\end{array}$ & $163 / 185$ & $267 / 81$ & $\begin{array}{c}\text { Median } \\
36\end{array}$ & $\begin{array}{l}\text { RFS, CSS, } \\
\text { OS }\end{array}$ \\
\hline $\begin{array}{l}\text { Tan et } \\
\text { al[14] }\end{array}$ & 2018 & China & 2003-2015 & 620 & $\begin{array}{l}\text { Mean } \pm \text { SD } \\
65.7 \pm 11.3\end{array}$ & $355 / 265$ & $350 / 161 / 109$ & $\begin{array}{c}\begin{array}{c}\text { Median } \\
\text { (range) }\end{array} \\
51(1-168) \\
\end{array}$ & $\begin{array}{l}\text { RFS, CSS, } \\
\text { OS }\end{array}$ \\
\hline $\begin{array}{l}\text { Kohada et } \\
\text { al[15] }\end{array}$ & 2018 & Japan & 1999-2016 & 148 & $\begin{array}{c}\text { Median (IQR) } \\
71(64-78)\end{array}$ & $112 / 36$ & $82 / 66$ & $\begin{array}{c}\text { Median (IQR) } \\
\text { 35.5(12-66) }\end{array}$ & RFS, CSS \\
\hline $\begin{array}{l}\text { Abe et } \\
\text { al[16] }\end{array}$ & 2018 & Japan & $2000-2015$ & 214 & $\begin{array}{c}\text { Median } \\
\text { (range) }\end{array}$ & $151 / 63$ & $127 / 82 / 5$ & $\begin{array}{c}\text { Median (IQR) } \\
41(21-71)\end{array}$ & $\begin{array}{l}\text { RFS, CSS, } \\
\text { OS }\end{array}$ \\
\hline $\begin{array}{l}\text { Nakagawa } \\
\text { et al[17] }\end{array}$ & 2017 & Japan & 1996-2013 & 109 & $\begin{array}{c}\text { Median (IQR) } \\
\text { 71(64-77) }\end{array}$ & $67 / 42$ & $50 / 23 / 36$ & $\begin{array}{c}\text { Median (IQR) } \\
\text { 46.5(23.2- } \\
76.7)\end{array}$ & RFS, CSS \\
\hline $\begin{array}{l}\text { Inokuchi } \\
\text { et al[18] }\end{array}$ & 2017 & Japan & $2005-2011$ & 823 & $\begin{array}{c}\text { Median (IQR) } \\
71(63-77)\end{array}$ & $578 / 245$ & $434 / 375 / 14$ & $\begin{array}{c}\text { Median (IQR) } \\
\text { 59.8(23.3- } \\
66.2)\end{array}$ & CSS, OS \\
\hline $\begin{array}{l}\text { Ikeda et } \\
\text { al[19] }\end{array}$ & 2017 & Japan & 1985-2013 & 399 & $\begin{array}{c}\text { Median (IQR) } \\
67(62-75)\end{array}$ & $307 / 92$ & $213 / 186$ & $\begin{array}{c}\text { Median (IQR) } \\
43(17-89)\end{array}$ & RFS, CSS \\
\hline $\begin{array}{l}\text { Fan et } \\
\text { al[20] }\end{array}$ & 2017 & China & $2002-2013$ & 101 & $\begin{array}{c}\text { Median } \\
69\end{array}$ & $61 / 40$ & $55 / 43 / 3$ & $\begin{array}{c}\begin{array}{c}\text { Median } \\
\text { (range) }\end{array} \\
41.3(4.2- \\
106.5)\end{array}$ & RFS, CSS \\
\hline $\begin{array}{l}\text { Cho et } \\
\text { al[21] }\end{array}$ & 2017 & Korea & $2004-2015$ & 1,049 & $\begin{array}{c}\text { Median (IQR) } \\
\\
68.5(60.5- \\
74.3) \\
\end{array}$ & $759 / 290$ & $489 / 462 / 252$ & $\begin{array}{l}\text { Median (IQR) } \\
\text { 40(18.4-64.8) }\end{array}$ & $\begin{array}{l}\text { RFS, CSS, } \\
\text { OS }\end{array}$ \\
\hline $\begin{array}{l}\text { Abufaraj } \\
\text { et al[22] }\end{array}$ & 2017 & $\begin{array}{c}\text { Muti- } \\
\text { centers }\end{array}$ & 1990-2008 & 678 & $\begin{array}{c}\text { Median (IQR) } \\
69(63-76)\end{array}$ & $380 / 298$ & $478 / 200$ & $\begin{array}{c}\text { Median (IQR) } \\
37.5(20-66)\end{array}$ & $\begin{array}{c}\text { Recurrence, } \\
\text { CSM }\end{array}$ \\
\hline $\begin{array}{l}\text { Yan et } \\
\text { al[23] }\end{array}$ & 2016 & China & $2002-2012$ & 795 & NA & $462 / 333$ & $497 / 187 / 111$ & $\begin{array}{c}\text { Median (IQR) } \\
\text { 32(17-60) }\end{array}$ & $\begin{array}{l}\text { RFS, CSS, } \\
\text { OS }\end{array}$ \\
\hline $\begin{array}{l}\text { Kobayashi } \\
\text { et al[24] }\end{array}$ & 2016 & Japan & 1990-2011 & 839 & $\begin{array}{c}\text { Median (IQR) } \\
70.4(63-78)\end{array}$ & $610 / 229$ & NA & $\begin{array}{c}\text { Median (IQR) } \\
34(17-63)\end{array}$ & $\begin{array}{l}\text { Recurrence, } \\
\text { CSS }\end{array}$ \\
\hline $\begin{array}{l}\text { Kang et } \\
\text { al[25] }\end{array}$ & 2016 & Korea & 2004-2014 & 566 & $\begin{array}{c}\text { Median (IQR) } \\
70(62-75) \\
\end{array}$ & $401 / 165$ & $258 / 308$ & $\begin{array}{c}\text { Median) } \\
33.8 \\
\end{array}$ & $\begin{array}{l}\text { RFS, CSS, } \\
\text { OS }\end{array}$ \\
\hline $\begin{array}{l}\text { Fukushima } \\
\text { et al[26] }\end{array}$ & 2016 & Japan & $2001-2015$ & 81 & $\begin{array}{c}\text { Median } \\
\text { (range) } \\
71(41-87)\end{array}$ & $53 / 28$ & $36 / 31 / 14$ & $\begin{array}{c}\begin{array}{c}\text { Median } \\
\text { (range) }\end{array} \\
41(4-170)\end{array}$ & CSS, OS \\
\hline $\begin{array}{l}\text { Mathieu et } \\
\text { al[27] }\end{array}$ & 2015 & $\begin{array}{c}\text { Muti- } \\
\text { centers }\end{array}$ & 1990-2008 & 732 & $\begin{array}{c}\text { Median (IQR) } \\
70(63-76)\end{array}$ & $414 / 318$ & $518 / 214$ & $\begin{array}{c}\text { Median(range) } \\
\text { 35(16-64) }\end{array}$ & RFS,CSS \\
\hline $\begin{array}{l}\text { Lee et } \\
\text { al[28] }\end{array}$ & 2015 & Korea & 1986-2013 & 344 & $\begin{array}{c}\text { Mean } \pm \text { SD } \\
65.1 \pm 10.6\end{array}$ & $240 / 104$ & $146 / 147 / 51$ & $\begin{array}{c}\text { Median(range) } \\
53.9(1-297) \\
\end{array}$ & CSS, OS \\
\hline
\end{tabular}




\begin{tabular}{|c|c|c|c|c|c|c|c|c|c|}
\hline $\begin{array}{l}\text { Lee et } \\
\text { al[29] }\end{array}$ & 2015 & China & 2004-2010 & 250 & NA & 108/142 & $129 / 122$ & $\begin{array}{c}\text { Median } \\
41 \\
\end{array}$ & CSS \\
\hline $\begin{array}{l}\text { Park et } \\
\text { al[30] }\end{array}$ & 2014 & Korea & $\begin{array}{l}1991-2010 \\
\end{array}$ & 392 & $\begin{array}{c}\text { Median(range) } \\
64(29-86)\end{array}$ & 299/93 & NA & $\begin{array}{c}\text { Median(range) } \\
47.6(2-257)\end{array}$ & RFS, CSS \\
\hline $\begin{array}{l}\text { Lee et } \\
\text { al[31] }\end{array}$ & 2014 & $\begin{array}{c}\text { Muti- } \\
\text { centers }\end{array}$ & $\begin{array}{l}1991-2008 \\
\end{array}$ & 622 & $\begin{array}{c}\text { Median (IQR) } \\
69(63-76)\end{array}$ & $346 / 276$ & $452 / 170$ & $\begin{array}{c}\text { Median (IQR) } \\
27(12-53)\end{array}$ & $\begin{array}{c}\text { Recurrence, } \\
\text { CSM }\end{array}$ \\
\hline $\begin{array}{l}\text { Krabbe et } \\
\text { al[32] }\end{array}$ & 2014 & USA & $2000-2012$ & 122 & $\begin{array}{c}\text { Median(range) } \\
69(35-92)\end{array}$ & $77 / 45$ & $88 / 34$ & $\begin{array}{c}\text { Median(range) } \\
32(1-149)\end{array}$ & CSS \\
\hline $\begin{array}{l}\text { Kluth et } \\
\text { al[33] }\end{array}$ & 2014 & $\begin{array}{c}\text { Muti- } \\
\text { centers }\end{array}$ & 1975-2012 & 242 & $\begin{array}{c}\text { Median (IQR) } \\
70(63-77)\end{array}$ & $175 / 67$ & $145 / 83 / 11$ & $\begin{array}{c}\text { Median } \\
9\end{array}$ & CSM \\
\hline $\begin{array}{l}\text { Liu et } \\
\text { al[34] }\end{array}$ & 2013 & China & $\begin{array}{l}1999-2010 \\
\end{array}$ & 421 & $\begin{array}{c}\text { Median (IQR) } \\
62(51-70) \\
\end{array}$ & $285 / 136$ & $225 / 196$ & NA & CSS \\
\hline $\begin{array}{l}\text { Hurel et } \\
\text { al[35] }\end{array}$ & 2013 & France & $1995-2010$ & 551 & $\begin{array}{c}\text { Median (IQR) } \\
\text { 69.4(61.8- } \\
76.4)\end{array}$ & $365 / 188$ & $302 / 169 / 80$ & $\begin{array}{c}\text { Median (IQR) } \\
\text { 26.8(10.3- } \\
\text { 48.7) }\end{array}$ & RFS, CSS \\
\hline $\begin{array}{l}\text { Milojevic } \\
\text { et al[36] }\end{array}$ & 2012 & Serbia & 1999-2009 & 133 & $\begin{array}{c}\text { Mean } \pm \text { SD } \\
66.7 \pm 8.9\end{array}$ & $77 / 56$ & $88 / 45$ & $\begin{array}{c}\text { Median(range) } \\
\text { 35(2-113) }\end{array}$ & $\begin{array}{c}\text { Recurrence, } \\
\text { CSS }\end{array}$ \\
\hline $\begin{array}{l}\text { Godfrey et } \\
\text { al[37] }\end{array}$ & 2012 & USA & $1990-2010$ & 222 & $\begin{array}{c}\text { Mean } \pm \text { SD } \\
70 \pm 11.4 \\
\end{array}$ & $124 / 87$ & $170 / 41$ & $\begin{array}{c}\text { Median (IQR) } \\
\text { 27(11-65.5) } \\
\end{array}$ & OS \\
\hline $\begin{array}{l}\text { Novara et } \\
\text { al[38] }\end{array}$ & 2010 & $\begin{array}{c}\text { Muti- } \\
\text { centers }\end{array}$ & $1987-2008$ & 762 & $\begin{array}{c}\text { Median (IQR) } \\
68(61-75)\end{array}$ & 527/235 & $401 / 232 / 48$ & $\begin{array}{c}\text { Median (IQR) } \\
34(15-65)\end{array}$ & $\begin{array}{c}\text { Recurrence, } \\
\text { CSM }\end{array}$ \\
\hline $\begin{array}{l}\text { Kim et } \\
\text { al[39] }\end{array}$ & 2010 & Korea & 1986-2006 & 238 & $\begin{array}{c}\text { Median(range) } \\
64.1(25-91)\end{array}$ & $164 / 74$ & $134 / 104$ & $\begin{array}{c}\text { Median(range) } \\
64.1(25-91)\end{array}$ & RFS, CSS \\
\hline $\begin{array}{l}\text { Margulis } \\
\text { et al[40] }\end{array}$ & 2009 & $\begin{array}{c}\text { Muti- } \\
\text { centers }\end{array}$ & 1992-2006 & 1,363 & $\begin{array}{l}\text { Mean } \pm \text { SD } \\
69.7 \pm 11.1\end{array}$ & $921 / 442$ & $878 / 463 / 22$ & $\begin{array}{c}\text { Median(range) } \\
37.2(1.2-250)\end{array}$ & $\begin{array}{c}\text { Recurrence, } \\
\text { CSM }\end{array}$ \\
\hline
\end{tabular}

Table 2. Tumor characteristics of the included studies in this meta-analysis 


\begin{tabular}{|c|c|c|c|c|c|c|c|c|c|c|}
\hline Study & $\begin{array}{l}\text { Staging } \\
\text { system }\end{array}$ & $\begin{array}{l}\text { Grading } \\
\text { system }\end{array}$ & $\begin{array}{l}\mathrm{LVI}+ \\
/ \mathrm{LVI} \text { - }\end{array}$ & $\begin{array}{c}\text { Stage } \\
1-2 / 3-4\end{array}$ & $\begin{array}{l}\text { Grade } \\
1-2 / 3 \\
\end{array}$ & $\begin{array}{l}\text { LNM-/ } \\
\text { LNM+ }\end{array}$ & $\begin{array}{l}\text { Unifocal/ } \\
\text { Multifocal }\end{array}$ & $\begin{array}{l}\text { Papillary/ } \\
\text { Sessile }\end{array}$ & $\begin{array}{c}\mathrm{TN}+/ \\
\mathrm{TN}-\end{array}$ & $\begin{array}{c}\text { PSM+I } \\
\text { PSM- }\end{array}$ \\
\hline Liu et al[10] & 2008 AJCC & $\begin{array}{c}2016 \\
\text { WHO/ } \\
\text { ISUP }\end{array}$ & $28 / 152$ & $115 / 65$ & $91 / 89$ & $169 / 11$ & $173 / 7$ & NA & $7 / 173$ & NA \\
\hline Li et al[11] & $2002 \mathrm{AJCC}$ & $\begin{array}{c}1973 \\
\text { WHO/ } \\
\text { ISUP }\end{array}$ & $46 / 839$ & $623 / 262$ & $518 / 367$ & $823 / 62$ & NA & $771 / 114$ & $114 / 771$ & NA \\
\hline Jan et al[12] & 2009 AJCC & $\begin{array}{c}2004 \\
\text { WHO/ } \\
\text { ISUP }\end{array}$ & $115 / 299$ & $244 / 180$ & $22 / 402$ & $399 / 25$ & $308 / 116$ & $97 / 278$ & $86 / 338$ & NA \\
\hline $\begin{array}{l}\text { Aydin et } \\
\text { al[13] }\end{array}$ & 2002 AJCC & $\begin{array}{c}1998 \\
\text { WHO/ } \\
\text { ISUP } \\
\end{array}$ & $98 / 250$ & $191 / 157$ & NA & $314 / 34$ & $270 / 78$ & $286 / 62$ & $62 / 286$ & NA \\
\hline $\begin{array}{l}\text { Tan et } \\
\text { al[14] }\end{array}$ & 2002 AJCC & $\begin{array}{l}\text { WHO/ } \\
\text { ISUP }\end{array}$ & $100 / 520$ & $310 / 310$ & $158 / 462$ & $554 / 62$ & $517 / 103$ & $193 / 427$ & NA & $50 / 570$ \\
\hline $\begin{array}{l}\text { Kohada et } \\
\text { al[15] }\end{array}$ & $2002 \mathrm{AJCC}$ & $\begin{array}{c}1998 \\
\text { WHO/ } \\
\text { ISUP } \\
\end{array}$ & $55 / 93$ & $82 / 66$ & $60 / 88$ & $140 / 8$ & $148 / 0$ & NA & NA & $12 / 136$ \\
\hline $\begin{array}{l}\text { Abe et } \\
\text { al[16] }\end{array}$ & 2002 AJCC & $\begin{array}{c}1973 \\
\text { WHO/ } \\
\text { ISUP }\end{array}$ & $96 / 118$ & $121 / 83$ & $101 / 113$ & $195 / 19$ & $209 / 5$ & NA & NA & $11 / 203$ \\
\hline $\begin{array}{l}\text { Nakagawa } \\
\text { et al[17] }\end{array}$ & 2009 AJCC & $\begin{array}{c}2004 \\
\text { WHO/ } \\
\text { ISUP }\end{array}$ & $78 / 31$ & $0 / 109$ & $40 / 69$ & $21 / 88$ & $73 / 36$ & NA & NA & $9 / 100$ \\
\hline $\begin{array}{l}\text { Inokuchi et } \\
\text { al[18] }\end{array}$ & 2002 AJCC & NA & $252 / 52$ & $459 / 324$ & $444 / 379$ & $787 / 26$ & $809 / 14$ & $\overline{\mathrm{NA}}$ & NA & $34 / 789$ \\
\hline $\begin{array}{l}\text { Ikeda et } \\
\text { al[19] }\end{array}$ & 2002 AJCC & $\begin{array}{c}1973 \\
\text { WHO/ } \\
\text { ISUP }\end{array}$ & $138 / 236$ & $237 / 162$ & $285 / 109$ & $359 / 40$ & $399 / 0$ & $\overline{\mathrm{NA}}$ & NA & $32 / 358$ \\
\hline $\begin{array}{l}\text { Fan et } \\
\text { al[20] }\end{array}$ & $2002 \mathrm{AJCC}$ & $\begin{array}{c}1998 \\
\text { WHO/ } \\
\text { ISUP }\end{array}$ & $14 / 87$ & $47 / 54$ & $25 / 76$ & $92 / 9$ & $91 / 10$ & $60 / 31$ & NA & NA \\
\hline $\begin{array}{l}\text { Cho et } \\
\text { al[21] }\end{array}$ & 2009 AJCC & $\begin{array}{c}1998 \\
\text { WHO/ } \\
\text { ISUP } \\
\end{array}$ & $202 / 847$ & $623 / 426$ & $304 / 705$ & $965 / 84$ & $889 / 160$ & NA & NA & NA \\
\hline $\begin{array}{l}\text { Abufaraj et } \\
\text { al[22] }\end{array}$ & $2002 \mathrm{AJCC}$ & $\begin{array}{c}1973 \\
\text { WHO/ } \\
\text { ISUP }\end{array}$ & $135 / 543$ & $452 / 226$ & $174 / 504$ & $629 / 49$ & $533 / 145$ & $558 / 120$ & 597/81 & NA \\
\hline $\begin{array}{l}\text { Yan et } \\
\text { al[23] }\end{array}$ & 2010 AJCC & $\begin{array}{c}1998 \\
\text { WHO/ } \\
\text { ISUP } \\
\end{array}$ & $169 / 626$ & $390 / 405$ & $212 / 583$ & $711 / 84$ & $684 / 111$ & $256 / 539$ & NA & $76 / 719$ \\
\hline $\begin{array}{l}\text { Kobayashi } \\
\text { et al[24] }\end{array}$ & AJCC & $\begin{array}{c}1973 \\
\text { WHO/ } \\
\text { ISUP }\end{array}$ & $326 / 513$ & $415 / 424$ & $347 / 492$ & $783 / 56$ & $715 / 124$ & NA & NA & NA \\
\hline $\begin{array}{l}\text { Kang et } \\
\text { al[25] }\end{array}$ & AJCC & $\begin{array}{c}1998 \\
\text { WHO/ } \\
\text { ISUP } \\
\end{array}$ & $119 / 447$ & $346 / 220$ & $178 / 388$ & NA & $517 / 49$ & NA & NA & NA \\
\hline $\begin{array}{l}\text { Fukushima } \\
\text { et al[26] }\end{array}$ & $2002 \mathrm{AJCC}$ & $\begin{array}{c}1973 \\
\text { WHO/ } \\
\text { ISUP }\end{array}$ & $50 / 31$ & $37 / 44$ & $31 / 50$ & $74 / 7$ & $67 / 14$ & NA & NA & NA \\
\hline $\begin{array}{l}\text { Mathieu et } \\
\text { al[27] }\end{array}$ & 2002 AJCC & $\begin{array}{c}1998 \\
\text { WHO/ } \\
\text { ISUP } \\
\end{array}$ & $153 / 579$ & $480 / 252$ & $187 / 454$ & $677 / 55$ & $577 / 155$ & $601 / 131$ & $97 / 635$ & $\mathrm{NA}$ \\
\hline $\begin{array}{l}\text { Lee et } \\
\text { al[28] }\end{array}$ & 2010 AJCC & $\begin{array}{c}1998 \\
\text { WHO/ } \\
\text { ISUP }\end{array}$ & $86 / 258$ & $144 / 200$ & $53 / 291$ & $265 / 79$ & $293 / 51$ & $\overline{\mathrm{NA}}$ & NA & NA \\
\hline $\begin{array}{l}\text { Lee et } \\
\text { al[29] }\end{array}$ & AJCC & $\begin{array}{c}2004 \\
\text { WHO/ } \\
\text { ISUP } \\
\end{array}$ & $60 / 190$ & $166 / 84$ & $57 / 193$ & $232 / 18$ & $191 / 59$ & NA & NA & NA \\
\hline $\begin{array}{l}\text { Park et } \\
\text { al[30] }\end{array}$ & $1997 \mathrm{AJCC}$ & $\begin{array}{c}1973 \\
\text { WHO/ } \\
\text { ISUP } \\
\end{array}$ & 89/303 & $248 / 144$ & 196/196 & $357 / 35$ & NA & $265 / 127$ & NA & $25 / 367$ \\
\hline $\begin{array}{l}\text { Lee et } \\
\text { al[31] }\end{array}$ & 2002 AJCC & $\begin{array}{c}2004 \\
\text { WHO/ } \\
\text { ISUP }\end{array}$ & $140 / 482$ & $396 / 226$ & $164 / 458$ & $569 / 53$ & $498 / 124$ & $518 / 104$ & $85 / 537$ & NA \\
\hline $\begin{array}{l}\text { Krabbe et } \\
\text { al[32] }\end{array}$ & 2010 AJCC & NA & $28 / 94$ & $87 / 35$ & $27 / 95$ & $113 / 9$ & $63 / 59$ & $80 / 42$ & NA & NA \\
\hline
\end{tabular}




\begin{tabular}{|c|c|c|c|c|c|c|c|c|c|c|}
\hline $\begin{array}{l}\text { Kluth et } \\
\text { al[33] }\end{array}$ & 2010 AJCC & $\begin{array}{c}2004 \\
\text { WHO/ } \\
\text { ISUP }\end{array}$ & $131 / 111$ & $76 / 166$ & NA & $191 / 51$ & $139 / 60$ & $83 / 47$ & $70 / 159$ & NA \\
\hline Liu et al[34] & 2002 AJCC & $\begin{array}{c}1998 \\
\text { WHO/ } \\
\text { ISUP }\end{array}$ & $101 / 320$ & $248 / 173$ & $215 / 206$ & $325 / 96$ & $288 / 133$ & NA & NA & $36 / 385$ \\
\hline $\begin{array}{l}\text { Hurel et } \\
\text { al[35] }\end{array}$ & 2009 AJCC & $\begin{array}{c}1973 \\
\text { WHO/ } \\
\text { ISUP }\end{array}$ & $163 / 388$ & $266 / 246$ & $331 / 415$ & $504 / 47$ & $471 / 80$ & NA & NA & $53 / 498$ \\
\hline $\begin{array}{l}\text { Milojevic et } \\
\text { al[36] }\end{array}$ & 1997 AJCC & $\begin{array}{c}1998 \\
\text { WHO/ } \\
\text { ISUP }\end{array}$ & $78 / 55$ & $47 / 86$ & $46 / 87$ & $128 / 5$ & $86 / 47$ & NA & NA & NA \\
\hline $\begin{array}{l}\text { Godfrey et } \\
\text { al[37] }\end{array}$ & 2010 AJCC & $\begin{array}{c}1998 \\
\text { WHO/ } \\
\text { ISUP }\end{array}$ & $68 / 143$ & $137 / 74$ & $77 / 134$ & $197 / 14$ & $\begin{array}{c}\text { Mean } \pm \\
\text { SD } \\
9.03 \pm 5.2\end{array}$ & NA & NA & $18 / 193$ \\
\hline $\begin{array}{l}\text { Novara et } \\
\text { al[38] }\end{array}$ & 2002 AJCC & $\begin{array}{c}1973 \\
\text { WHO/ } \\
\text { ISUP }\end{array}$ & $148 / 614$ & $508 / 254$ & $320 / 442$ & $713 / 49$ & $633 / 48$ & $\overline{\mathrm{NA}}$ & NA & NA \\
\hline $\begin{array}{l}\text { Kim et } \\
\text { al[39] }\end{array}$ & 1997AJCC & $\begin{array}{c}1973 \\
\text { WHO/ } \\
\text { ISUP }\end{array}$ & $31 / 207$ & $131 / 107$ & $95 / 143$ & NA & $182 / 56$ & $185 / 53$ & NA & $10 / 228$ \\
\hline $\begin{array}{l}\text { Margulis et } \\
\text { al[40] }\end{array}$ & 2002 AJCC & $\begin{array}{c}1998 \\
\text { WHO/ } \\
\text { ISUP }\end{array}$ & $338 / 1,025$ & $852 / 511$ & $495 / 868$ & $455 / 135$ & $1,341 / 22$ & $983 / 380$ & $294 / 1,069$ & NA \\
\hline
\end{tabular}

Table 3. Summary and subgroup analysis of pooled ORs for the eligible studies 


\begin{tabular}{|c|c|c|c|c|c|c|}
\hline \multirow[t]{2}{*}{ Analysis specification } & \multirow[t]{2}{*}{ No. of studies } & \multicolumn{2}{|c|}{ Study heterogeneity } & \multirow[t]{2}{*}{ Effects model } & \multirow[t]{2}{*}{ Pooled HR(95\% CI) } & \multirow[t]{2}{*}{ P-Value } \\
\hline & & $\mathrm{I}^{2}(\%)$ & $\mathrm{P}_{\text {heterogeneity }}$ & & & \\
\hline \multicolumn{7}{|l|}{ CSS } \\
\hline Overall & 24 & 69.9 & $<0.001$ & Random & $1.62 \square 1.49,1.76 \square$ & $<0.001$ \\
\hline \multicolumn{7}{|l|}{ Geographical region } \\
\hline Asia & 19 & 65.1 & $<0.001$ & Random & $1.66 \square 1.52,1.81 \square$ & $<0.001$ \\
\hline non-Asian & 5 & 82.5 & $<0.001$ & Random & $1.51 \square 1.19,1.91 \square$ & 0.001 \\
\hline \multicolumn{7}{|l|}{ Year of publication } \\
\hline$\geq 2014$ & 16 & 74 & $<0.001$ & Random & $1.67 \square 1.49,1.86 \square$ & $<0.001$ \\
\hline$<2014$ & 8 & 59.4 & 0.016 & Random & $1.55 \square 1.37,1.76 \square$ & $<0.001$ \\
\hline \multicolumn{7}{|l|}{ No. of patients } \\
\hline$\geq 500$ & 9 & 77.5 & $<0.001$ & Random & $1.83 \square 1.63,2.06 \square$ & $<0.001$ \\
\hline$<500$ & 15 & 34.8 & 0.090 & Fixed & $1.45 \square 1.33,1.59 \square$ & $<0.001$ \\
\hline \multicolumn{7}{|l|}{ Stage $\left(\mathrm{T}_{3}+\mathrm{T}_{4} \%\right)$} \\
\hline$\geq 40$ & 16 & 68.8 & $<0.001$ & Random & $1.64 \square 1.49,1.81 \square$ & $<0.001$ \\
\hline$<40$ & 8 & 74.3 & $<0.001$ & Random & $1.58 \square 1.34,1.87 \square$ & 0.001 \\
\hline \multicolumn{7}{|l|}{ Grade $\left(\mathrm{G}_{2}+\mathrm{G}_{3} \%\right)$} \\
\hline$\geq 60$ & 15 & 51.6 & 0.011 & Random & $1.60 \square 1.48,1.73 \square$ & $<0.001$ \\
\hline$<60$ & 9 & 82.9 & $<0.001$ & Random & $1.70 \square 1.39,2.07 \square$ & $<0.001$ \\
\hline \multicolumn{7}{|l|}{ Median follow-up } \\
\hline$\geq 40$ months & 14 & 72.1 & $<0.001$ & Random & $1.65 \square 1.45,1.88 \square$ & $<0.001$ \\
\hline$<40$ months & 10 & 69 & $<0.001$ & Random & $1.59 \square 1.42,1.78 \square$ & $<0.001$ \\
\hline \multicolumn{7}{|l|}{ OS } \\
\hline Overall & 12 & 73.2 & $<0.001$ & Random & $1.55 \square 1.41,1.71 \square$ & $<0.001$ \\
\hline \multicolumn{7}{|l|}{ Geographical region } \\
\hline Asia & 10 & 76.5 & $<0.001$ & Random & $1.56 \square 1.40,1.74 \square$ & $<0.001$ \\
\hline non-Asian & 2 & 61.0 & 0.109 & Random & $1.49 \square 1.11,2.00 \square$ & $<0.001$ \\
\hline Year of publication & & & & & & \\
\hline$\geq 2014$ & 10 & 77.6 & $<0.001$ & Random & $1.54 \square 1.37,1.73 \square$ & $<0.001$ \\
\hline$<2014$ & 2 & 0 & 0.402 & Fixed & $1.58 \square 1.40,1.77 \square$ & $<0.001$ \\
\hline No. of patients & & & & & & \\
\hline$\geq 500$ & 4 & 83.1 & $<0.001$ & Random & $1.71 \square 1.48,1.97 \square$ & $<0.001$ \\
\hline$<500$ & 8 & 33.9 & 0.169 & Fixed & $1.43 \square 1.29,1.59 \square$ & $<0.001$ \\
\hline Stage $\left(\mathrm{T}_{3}+\mathrm{T}_{4} \%\right)$ & & & & & & \\
\hline$\geq 40$ & 10 & 71.2 & $<0.001$ & Random & $1.60 \square 1.45,1.78 \square$ & $<0.001$ \\
\hline$<40$ & 2 & 80.1 & 0.025 & Random & $1.33 \square 0.99,1.80 \square$ & 0.061 \\
\hline Grade $\left(\mathrm{G}_{3}+\mathrm{G}_{4} \%\right)$ & & & & & & \\
\hline$\geq 60$ & 9 & 0 & 0.449 & Fixed & $1.58 \square 1.50,1.66 \square$ & $<0.001$ \\
\hline$<60$ & 3 & 93.8 & $<0.001$ & Random & $1.54 \square 0.92,2.58 \square$ & 0.098 \\
\hline Median follow-up & & & & & & \\
\hline$\geq 40$ months & 7 & 82.6 & $<0.001$ & Random & $1.54 \square 1.30,1.81 \square$ & $<0.001$ \\
\hline$<40$ months & 5 & 29.4 & 0.225 & Fixed & $1.60 \square 1.47,1.75 \square$ & $<0.001$ \\
\hline RFS & & & & & & \\
\hline Overall & 15 & 78.6 & $<0.001$ & Random & $1.46 \square 1.32,1.61 \square$ & $<0.001$ \\
\hline Geographical region & & & & & & \\
\hline Asia & 12 & 69.3 & $<0.001$ & Random & $1.52 \square 1.38,1.67 \square$ & $<0.001$ \\
\hline non-Asian & 3 & 91.8 & $<0.001$ & Random & $1.28 \square 0.94,1.74 \square$ & 0.114 \\
\hline Year of publication & & & & & & \\
\hline$\geq 2014$ & 11 & 75.8 & $<0.001$ & Random & $1.50 \square 1.34,1.67 \square$ & $<0.001$ \\
\hline$<2014$ & 4 & 86.4 & $<0.001$ & Random & $1.38 \square 1.09,1.74 \square$ & 0.007 \\
\hline No. of patients & & & & & & \\
\hline$\geq 500$ & 7 & 88.2 & $<0.001$ & Random & $1.57 \square 1.36,1.81 \square$ & $<0.001$ \\
\hline$<500$ & 8 & 29.6 & 0.192 & Fixed & $1.34 \square 1.20,1.49 \square$ & $<0.001$ \\
\hline Stage $\left(\mathrm{T}_{3}+\mathrm{T}_{4} \%\right)$ & & & & & & \\
\hline$\geq 40$ & 11 & 68.9 & 0.061 & Random & $1.57 \square 1.31,1.88 \square$ & $<0.001$ \\
\hline$<40$ & 4 & 82.7 & 0.026 & Random & $1.84 \square 0.95,3.53 \square$ & 0.068 \\
\hline Grade $\left(\mathrm{G}_{3}+\mathrm{G}_{4} \%\right)$ & & & & & & \\
\hline$\geq 60$ & 4 & 45.8 & $<0.001$ & Random & $1.38 \square 1.25,1.51 \square$ & $<0.001$ \\
\hline$<60$ & 2 & 54.1 & 0.001 & Random & $1.71 \square 1.36,2.15 \square$ & $<0.001$ \\
\hline Median follow-up & & & & & & \\
\hline$\geq 40$ months & 9 & 46.8 & 0.059 & Random & $1.42 \square 1.30,1.57 \square$ & $<0.001$ \\
\hline$<40$ months & 6 & 89.2 & $<0.001$ & Random & $1.48 \square 1.23,1.79 \square$ & $<0.001$ \\
\hline
\end{tabular}


Table 4. Meta-analysis of LVI and clinicopathological features in UUTC patients.

\begin{tabular}{|c|c|c|c|c|c|c|}
\hline Variables & Studies & Pooled OR (95\% CI) & $P_{\text {Value }}$ & Model & Heterogeneity $I^{2}(\%)$ & $P_{\text {Heterogeneity }}$ \\
\hline TNM stage (III/IV vs. I/II) & 7 & $7.63(5.60-10.39)$ & $<0.001$ & $\mathrm{RE}$ & 44.2 & 0.097 \\
\hline Tumor grade (3 vs. 1/2) & 7 & $5.61(3.71-8.48)$ & $<0.001$ & $\mathrm{RE}$ & 45.2 & 0.090 \\
\hline Lymph node metastasis (yes vs. no) & 6 & $4.95(3.66-6.71)$ & $<0.001$ & $\mathrm{FE}$ & 0 & 0.625 \\
\hline Carcinoma in situ (yes vs. no) & 4 & $1.92(1.36-2.70)$ & $<0.001$ & $\mathrm{FE}$ & 0 & 0.826 \\
\hline Positive surgical margin (yes vs. no) & 3 & $4.38(2.71-7.07)$ & $<0.001$ & FE & 0 & 0.794 \\
\hline Multifocality (multifocal vs. unifocal) & 6 & $1.10(0.82-1.47)$ & 0.539 & FE & 43 & 0.119 \\
\hline gender (male vs. female) & 7 & $0.98(0.80-1.19)$ & 0.825 & $\mathrm{FE}$ & 0 & 0.675 \\
\hline
\end{tabular}

\section{Figures}




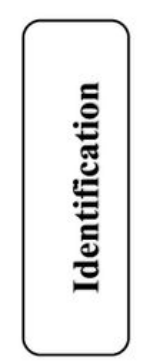

Web of Science 261 articles

EMBASE 205 articles

PubMed 532 articles
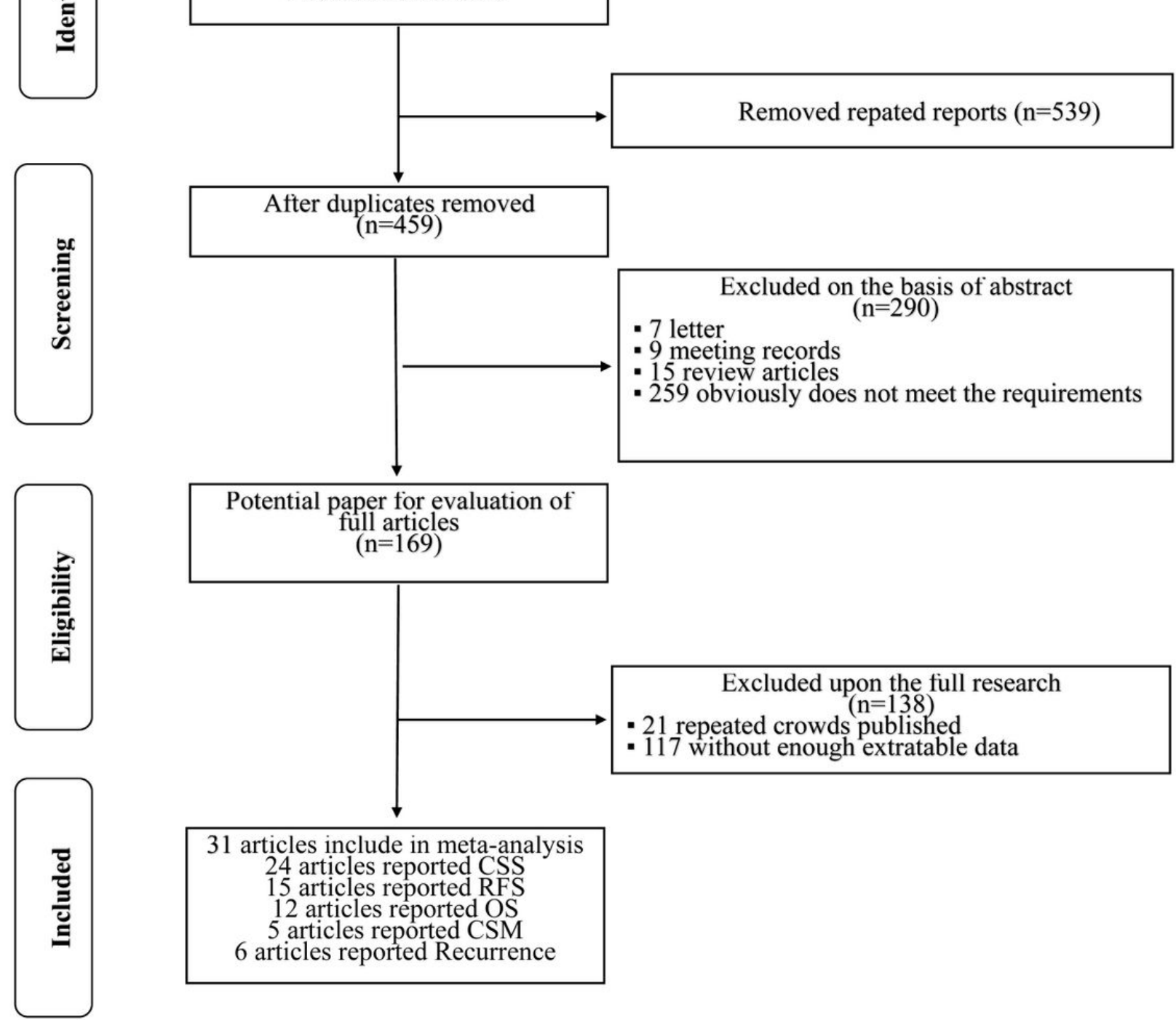

Figure 1

PRISMA flow chart of literature search and selection process. 
Study

$\%$

ID

$\mathrm{HR}(95 \% \mathrm{Cl}) \quad$ Weight

Liu et al 2019

Li et al 2019

Jan et al 2019

Aydin et al 2019

Tan et al 2018

Kohada et al 2018

Abe et al 2018

Nakagawa et al 2017

Inokuchi et al 2017

Ikeda et al 2017

Fan et al 2017

Cho et al 2017

Yan et al 2016

Kobayashi et al 2016

Kang et al 2016

Fukushima et al 2016

Mathieu et al 2015

Lee et al 2015

Lee et al 2015

Park et al 2014

Krabbe et al 2014

Hurel et al 2013

Milojevic et al 2012

Kim et al 2010

Overall $(\mathrm{I}$-squared $=69.6 \%, p=0.000)$

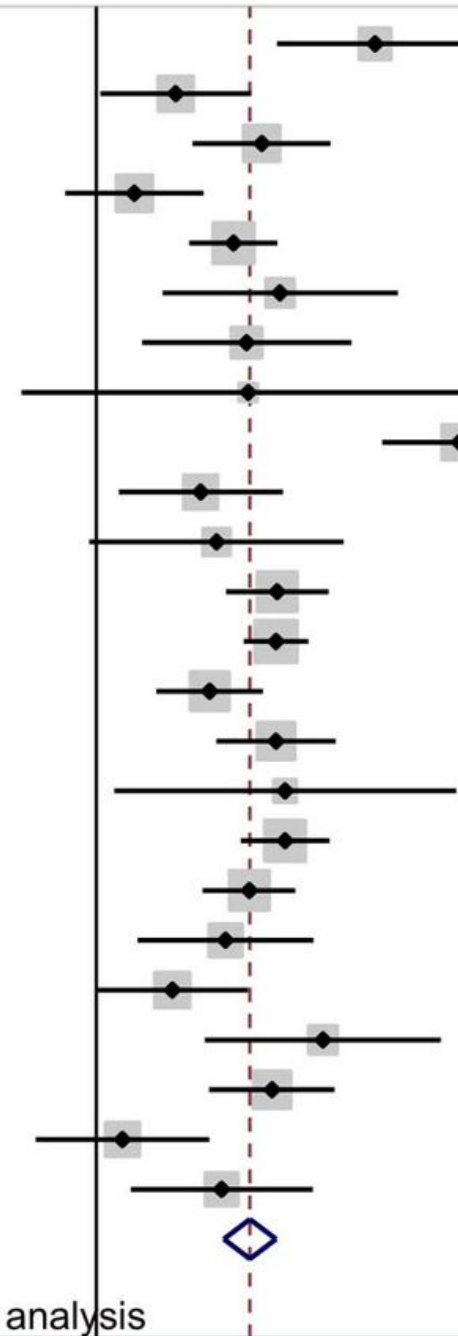

$2.41(1.77,3.29) 3.49$

$1.28(1.01,1.63) 4.37$

$1.69(1.36,2.09) 4.65$

$1.13(0.91,1.40) 4.64$

$1.54(1.34,1.77) 5.74$

$1.79(1.23,2.59) 2.88$

$1.61(1.16,2.24) 3.28$

$1.62(0.79,3.30) 1.12$

$3.15(2.47,4.02) 4.29$

$1.39(1.08,1.80) 4.11$

$1.46(0.98,2.18) 2.63$

$1.77(1.51,2.08) 5.43$

$1.76(1.59,1.95) 6.19$

$1.43(1.21,1.69) 5.33$

$1.76(1.46,2.13) 5.05$

$1.82(1.06,3.11) 1.75$

$1.81(1.58,2.08) 5.73$

$1.62(1.40,1.87) 5.64$

$1.50(1.14,1.99) 3.86$

$1.27(1.00,1.61) 4.37$

$2.05(1.41,2.97) 2.87$

$1.74(1.43,2.12) 4.92$

$1.09(0.83,1.43) 3.91$

$1.49(1.12,1.98) 3.76$

$1.62(1.49,1.76) 100.00$

NOTE: Weights are from random effects analysis

.249

1

4.02

Figure 2

Meta-analysis of the effect of LVI on CSS. 
$3 A$

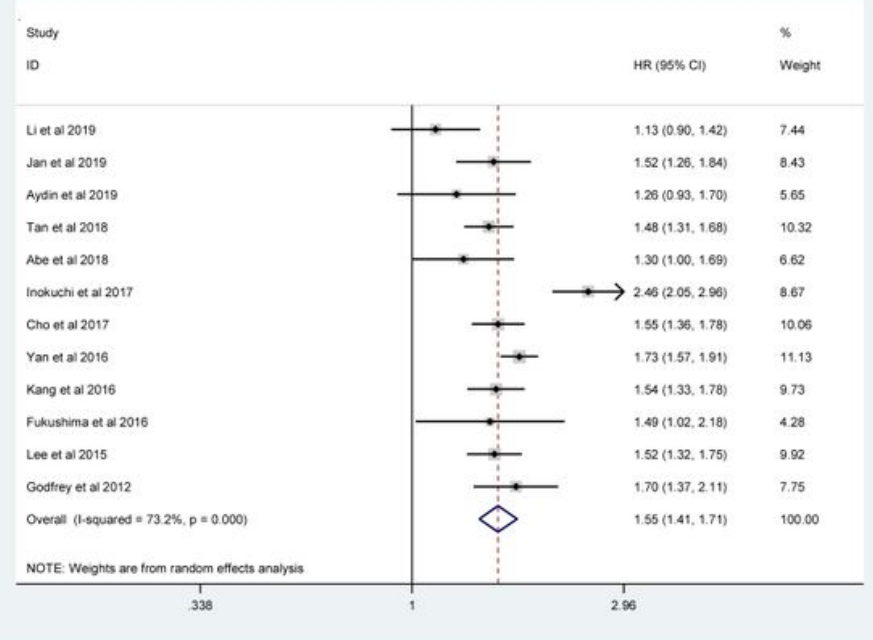

$3 \mathrm{C}$

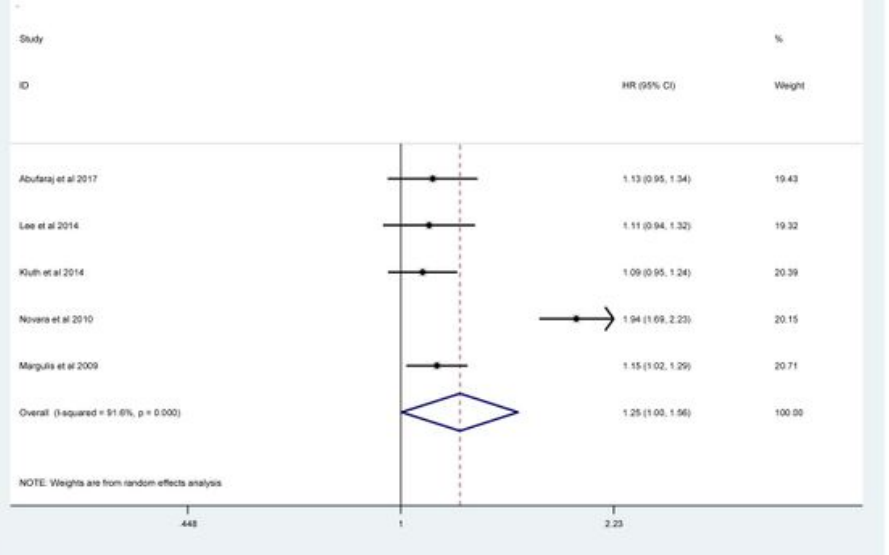

3B

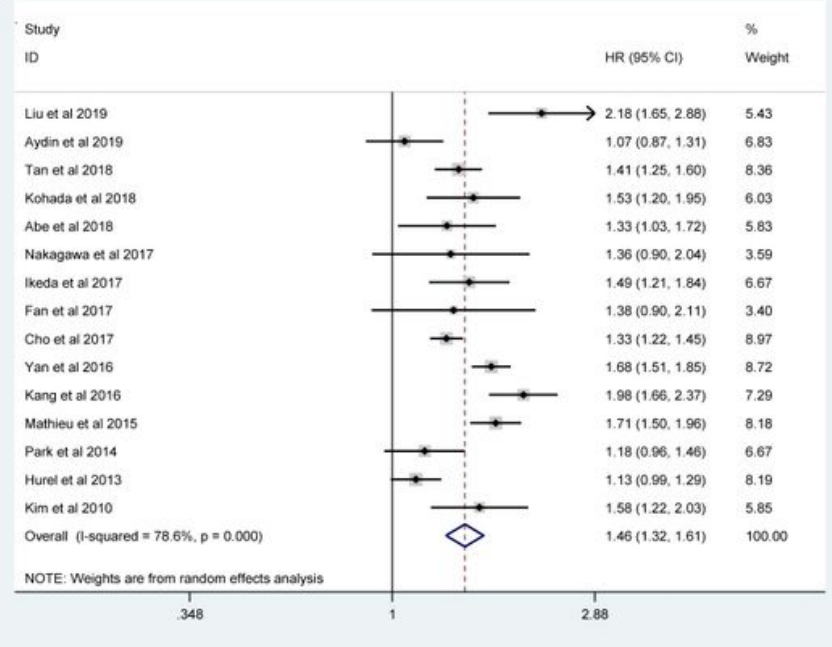

$3 \mathrm{D}$

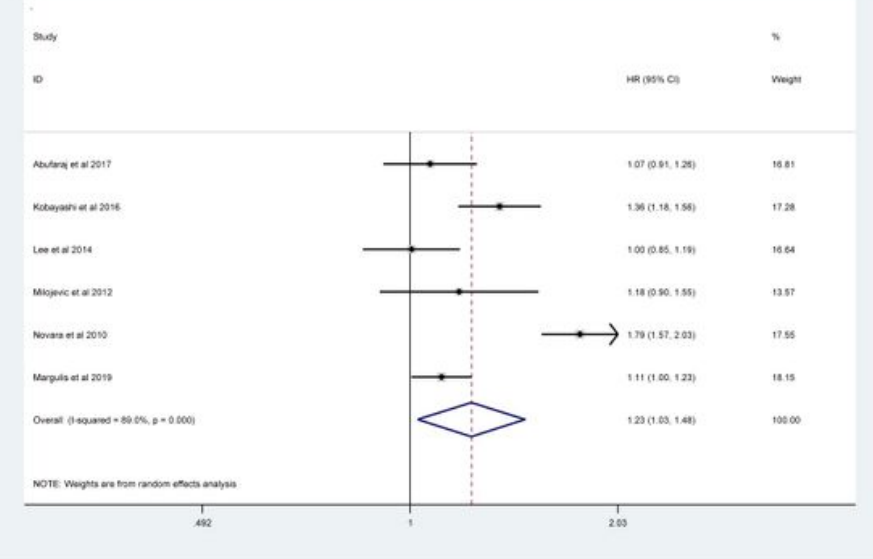

\section{Figure 3}

Forest plots assessing correlation of LVI and (A)OS, (B)RFS, (C)CSM, (D) recurrence in studies considering patients of UTUC. 

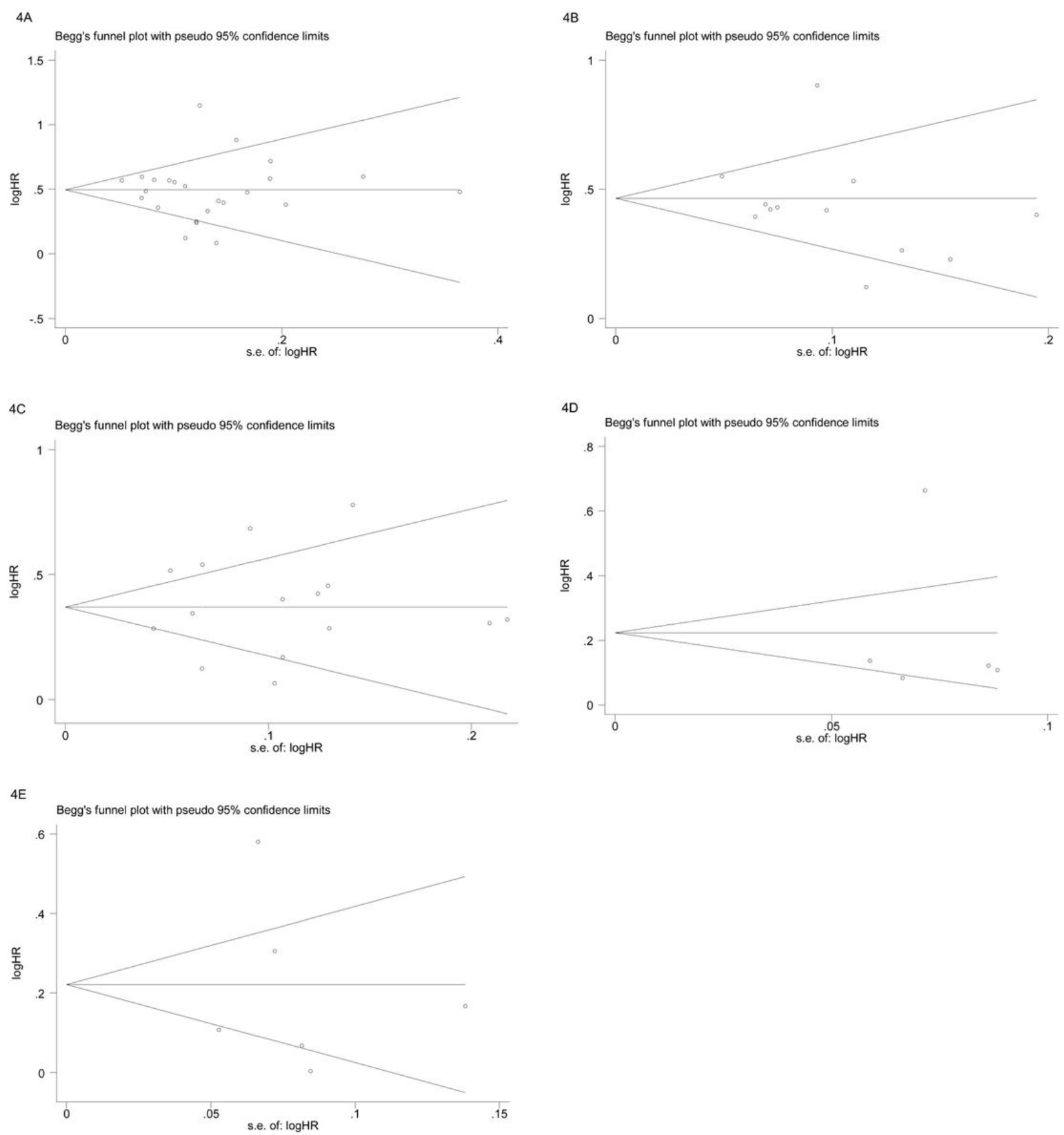

\section{Figure 4}

Funnel plots evaluating possible publication bias regarding: (A) CSS, (B) OS, (C) RFS, (D) CSM and (E) recurrence.

\section{Supplementary Files}

This is a list of supplementary files associated with this preprint. Click to download.

- FigureS2.tif

- FigureS3.tif

- FigureS1.tif

- TableS1.docx

- PRISMAchecklist.doc 